\title{
Local Laboratory Certification or Accreditation Document
}

National Cancer Institute

\section{Source}

National Cancer Institute. Local Laboratory Certification or Accreditation Document. NCI

Thesaurus. Code C115713.

Official records of certification by an accredited body that recognizes the competence of a local laboratory to participate in a clinical trial. 